\title{
Apresentado na I Jornada Científica do Esporte Coletivo Recife - PE, 2018. PREPARAÇÃO FÍSICA NOS ESPORTES COLETIVOS
}

\author{
Prof. Me. Edvaldo Tacão.
}

$\mathrm{Na}$ atualidade, discutir sobre Preparação Física nos esportes coletivos, acredita-se que se deve iniciar pelos objetivos de tal Preparação (objetivos; conteúdos, métodos, capacidades físicas, técnicas, táticas e emocionais) todos esses parâmetros estarão envolvidos na prática dessas modalidades. Em seguida, a organização (planejar, executar e controlar o treino) e logo após, sobre a sua avaliação e evolução dos atletas, através dos ciclos ou blocos de uma periodização. O planejamento e a periodização nos mostram a organização desses esportes atualmente. Como se distribui a carga de treinamento dentro de uma semana sem jogo e outra com um jogo no meio da semana e no final da mesma. Citado anteriormente, numa periodização do treinamento, pode-se trabalhar como os períodos pré-preparatório, período preparatório e o período de competição. No período pré preparatório, temos as avaliações físicas. No período preparatório são realizados os trabalhos com ênfase na preparação física específicas que dizem respeito às capacidades biomotoras e técnicas em grande volume; no período de competição trabalha-se a parte da especificidade do jogo. Entra em jogo também a rotina de pré-treino que o atleta realiza os meios de recuperação durante o período competitivo. A unidade de treino é composta da primeira parte, Introdução, a segunda parte principal e a terceira parte complementar. E ao final, será realizado o controle de carga do jogo, através do GPS, que monitoriza também os treinamentos na distância percorrida e nas ações de alta intensidade (com a velocidade maior de $25 \mathrm{~km} / \mathrm{h}$, por exemplo, no futebol). Treino e avaliação no dinamômetro isocinético, aferição através do reflotlon da creatina quinase... E por fim, como acompanhamento, teremos que ter sob nosso controle, uma planilha do controle minuciosa e individual de cada atleta, dessa forma poderemos controlar de perto o treino e a evolução dos indivíduos

atletas.

Palavras-chave: Preparação, Monitoramento, Avaliação.

Email: tacaorecife@gmail.com 